International Journal of Computer and Information System (IJCIS)

Peer Reviewed - International Journal

Vol : Vol. 01, Issue 02, August 2020

e-ISSN : 2745-9659

https://ijcis.net/index.php/ijcis/index

\title{
Transaction Processing System Analysis Using The Distribution Management System (DMS) Nexsoft Distribution 6 (ND6)
}

\author{
$1^{\text {st }}$ Isnawati Muslihah, ${ }^{\text {nd }}$ Sofia Agustin Nastura \\ ${ }^{1,2}$ Institut Teknologi Bisnis AAS Indonesia Surakarta \\ ${ }^{1,2}$ Jl. Slamet Riyadi No. 361 Windan, Makamhaji, Kartasura, Sukoharjo, Indonesia \\ ${ }^{1}$ isnawatimuslihah12345@gmail.com, ${ }^{2}$ snastura@gmail.com,
}

\begin{abstract}
Distribution Management system (DMS) is an application that manages almost the entire processing of sales orders, purchases, inventory management and financial accounting. The DMS application is only intended for specific types of distribution businesses than other types of businesses, which are at least able to provide a much higher level of functionality, specifically for the needs of distribution companies. This research was conducted at PT. Succeed which is a food distribution company. The daily transaction processing system at this company uses DMS Nexsoft Distribution 6 (ND6). NexSoft Distribution 6 (ND6) is the main operating system for any trading business in carrying out daily activities. NexSoft distribution is produced by PT. Paramadaksa Teknologi Nusantara which is a company engaged in Information Technology (IT), which is headquartered in the Tangerang area.
\end{abstract}

Keywords-DMS, Nexsoft, ND6, PT Sukses, Transaction Processing System.

\section{INTRODUCTION}

Information technology is a technology used to process data, including processing and manipulating data in various ways to obtain fairly accurate, relevant and timely information. A company needs an effective and efficient computerized system to carry out its daily work. Along with the development of the company, there are more and more collaborations that are established as well as high market demand so that it is difficult for distributors to manage company needs regarding the transaction processing system. Therefore, we need a system that can overcome this. Nexsoft Distribution 6 (ND6) can be used as a solution to solve this problem. ND6 is considered to be able to facilitate the transaction processing system that occurs at PT Sukses [1].

\section{RESEARCH METHODS}

The data collection method for this research is using qualitative research methods.

\subsection{Data Collection Methods}

The following data collection methods are as follows:

1. Interview

Interviews were conducted with admin staff of PT Sukses with the topic of discussing the Flow of Transaction Processing Systems using ND6 which took place at the PT Berhasil offices.

2. Observation

Observations are made directly at the PT Sukses office, observations are made on every transaction process that occurs when a sale occurs at PT Sukses until the use of the ND6 system.

3. Literature study

The necessary references or theories are obtained from several books on Management Information Systems (SIM) and the official website of Nexsoft.

\subsection{Systems Development Method}

The following methods in system development are as follows :
1. System Planning : Establish a framework and procedures for making information systems in accordance with company needs.

2. System Analysis : At this stage, what is done is the completeness of system data, computer security analysis, the effectiveness of using the system.

3. System Design : This application system design includes: Context Diagram, HIPO, DAD, Input Output Design,

4. System Implementation: This system is made with the Java programming language and uses the MySQL database.

5. System Testing : There are two Testing Systems: Functionality Testing and Questionnaire Testing [2].

\subsection{Management Information Systems}

Management Information System (MIS) is a computerbased system that provides information for multiple users with similar needs. Output information is used by managers and non managers in the company to make decisions in solving problems, Raymond McLeod Jr (1996: 54).

\subsection{Transaction Processing System}

According to Hanif al Fatta (2007), a transaction processing system (TPS) is a computerized information system developed to process large amounts of routine business transaction data to produce financial information. The main purpose of a system at this level is to track the flow of transactions through the company. At the operational level, the tasks, resources and objectives are predefined and highly structured.

\subsection{Distribution Management System (DMS)}

Distribution Management system (DMS) is an application that manages almost the entire processing of sales orders, purchases, inventory management and financial accounting. The DMS application is only intended for specific types of distribution businesses than other types of businesses, which are at least able to provide a much higher level of functionality, specifically for the needs of distribution companies. 
International Journal of Computer and Information System (IJCIS)

Peer Reviewed - International Journal

Vol : Vol. 01, Issue 02, August 2020

e-ISSN : 2745-9659

https://ijcis.net/index.php/ijcis/index

\subsection{Application Model}

The Nexsoft Distribution 6 (ND6) system uses offline web. In offline mode, it is sufficient to prepare a computer and some software to create a local web server or local host. In this offline mode system, the management of creating web pages can be done optimally before the data is ready to be uploaded to the internet web server.

\subsection{Java Programming Language}

The Nexsoft Distribution 6 (ND6) system uses the Java programming language. Java is a very popular programming language. This Java is Write Once, Run Anywhere (a program that is written once and can run on many platforms). Thus, it is not surprising that applications created using the Java programming language can be found in computer and smartphone environments without any significant differences. Just like programming in general, Java is a programming language that is capable of working with a database[3].

\subsection{MySQL databases}

The Nexsoft Distribution 6 (ND6) system uses the MySQL database. MySQL is a database management system (database management) using the basic command of SQL (Structured Query Language) which is quite well known. MySQL is an open source DBMS with two license forms, namely software (free software) and shareware (proprietary software of limited use). So MySQL is a free database server with the GNU General Public License (GPL) so that it can be used for personal or commercial purposes without having to pay for an existing license[4].

\section{RESULT AND ANALYSIS}

In the discussion, discussing the results of research in the form of system design as a whole are as follows:

\subsection{Computerized System Analysis}

Before using Nexsoft Dstribution 6 (ND6), PT succeeded in using the Nexus Distribution 95 (ND95) application. ND 95 includes 9 basic modules which are integrated or directly related to the daily activities of the distributor. However, ND95 was constrained by price and inventory settings. Therefore, a Nexsoft Distribution 6 (ND6) was created which was a solution to the problems that existed in ND95, because ND6 was considered more effective and efficient. Nexsoft Distribution 6 (ND) offers the latest unique features (proforma invoice, temporary warehouse, cash and credit customer segregation, 5 levels of discounts both in nominal and percentage terms, and more) which are common business practices in the world of commerce in Indonesia so that it can be directly used by middle-class companies (SMEs) - even companies that only have a few employees who often hold multiple roles and do not have high business process knowledge. The ND6 consists of 12 basic modules which are interconnected.

\subsection{System Design}

At this stage, system development and creation of new procedures are in accordance with the desired job requirements of the company.

\section{Contex Diagram}

Contex Diagram is a part that is used to show or describe the flow of data throughout the network, input and output. Identify the beginning and end of the initial and final data entering and the system output. Context Diagram of the transaction processing system at PT Sukses

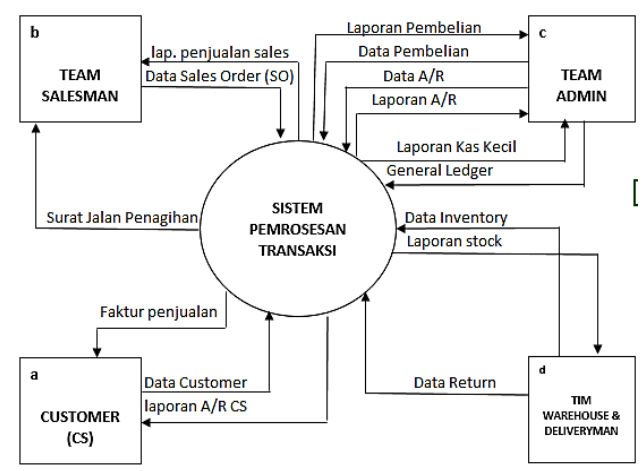

Figure 1. Context Diagram

\section{2. $\mathrm{HIPO}$}

HIPO (Input Process Output Hierarchy) is a system development tool and system documentation technique in programs. The most important goal of HIPO is to produce correct output and meet user requirements.

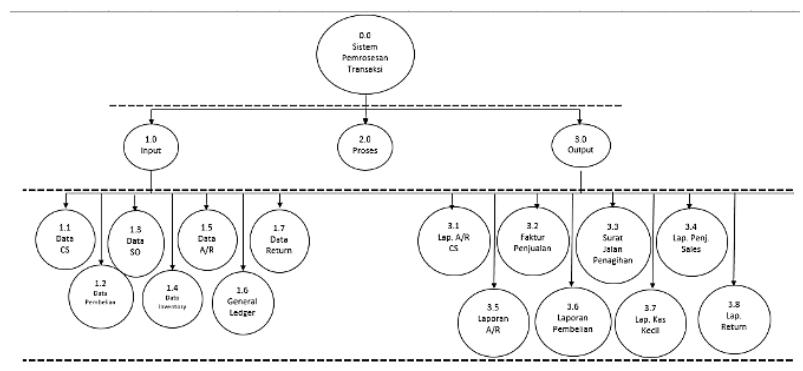

Figure 2. HIPO

\section{DAD (Data Flow Diagram)}

Data Flow Diagram (DAD) is a flow diagram that describes the flow from data to the system, DAD helps to understand the system in a logical, structured and clear manner. The following is DAD level 0 for transaction processing systems.

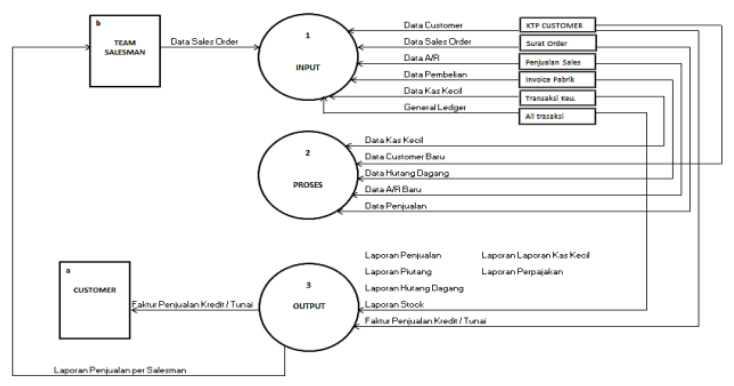

Figure 3. DAD Level 0

\subsection{System Implementation}

System implementation is the process of making a system in the form of designing a Nexsoft Distribution 6 (ND6) application:

1. Input sales data 
International Journal of Computer and Information System (IJCIS)

Peer Reviewed - International Journal

Vol : Vol. 01, Issue 02, August 2020

e-ISSN : 2745-9659

https://ijcis.net/index.php/ijcis/index

Display data input used to input scholarship recipient candidate data.

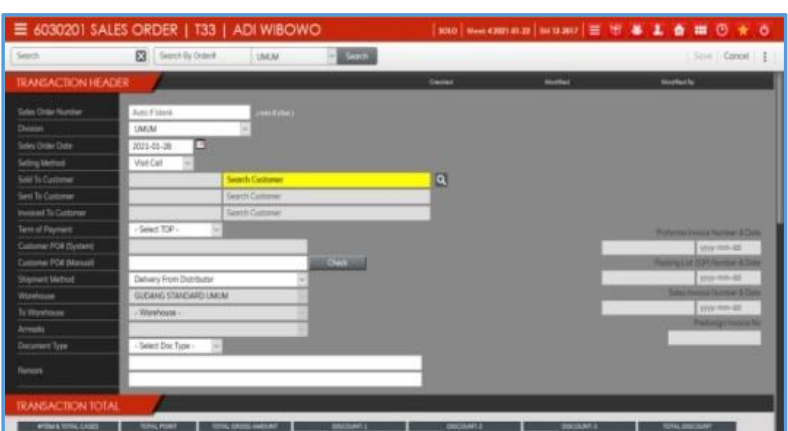

Figure 4. Sales Data Input Form

2. Display Application Manager Module

Display criteria setting form is used to make settings for the application.

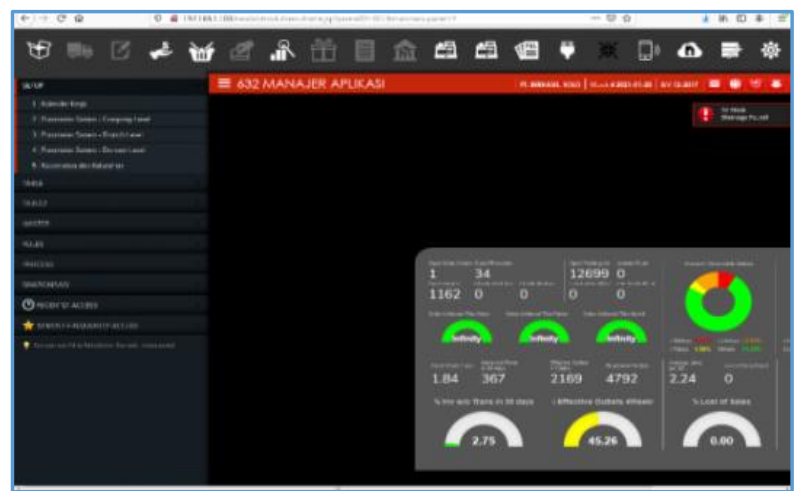

Figure 5. Application Manager Module Form

3. Display Report Results

Display of report results Transaction Processing System, namely Account Receiveable (A / R) Report. Here are the results of the report.

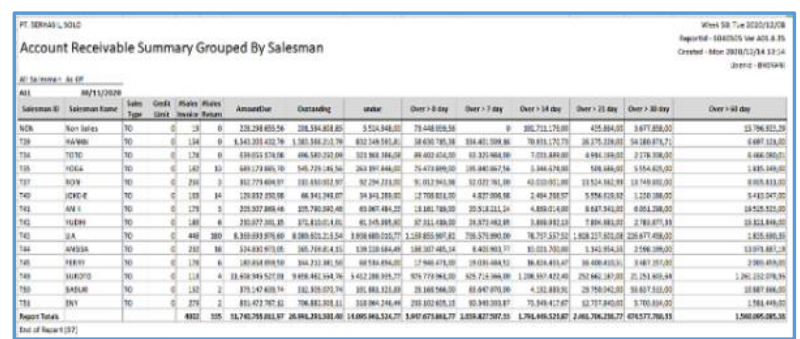

Figure 6. Report A/R

\subsection{System Testing}

Testing is the final part of a system process. The purpose of system testing is to test whether the system is what the user expects. The following is testing the system.

a. Functionality Testing

The functionality testing method used is testing using the Black Box testing method. The following are the test results with the Black Box in the form of a test table to produce the test values, as follows :
Table 1. Functionality Test

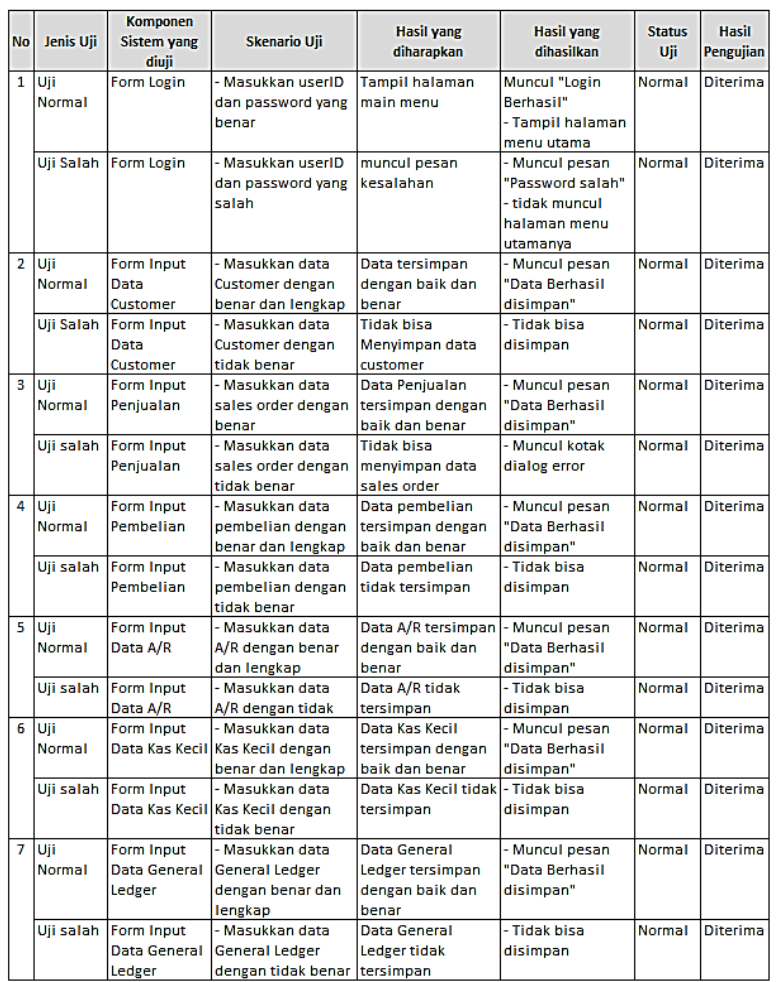

b. Quizoner Testing

This questionnaire test was conducted to test the system so that the results of the match between manual calculations and computer systems were known to produce valid calculations. Stage 1

In the process of determining the questionnaire test for this system, several respondents were involved. This can be seen in table 2 .

Table 2. Respondent Data 1

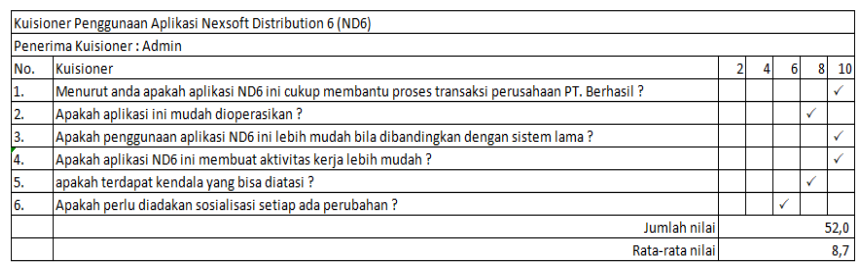

Table 2. Respondent Data 2

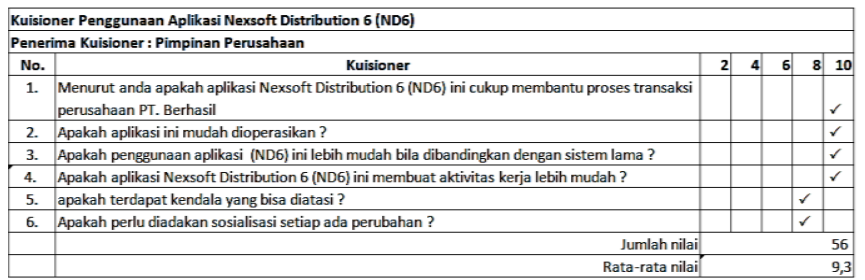

Table 3. Respondent Data 3

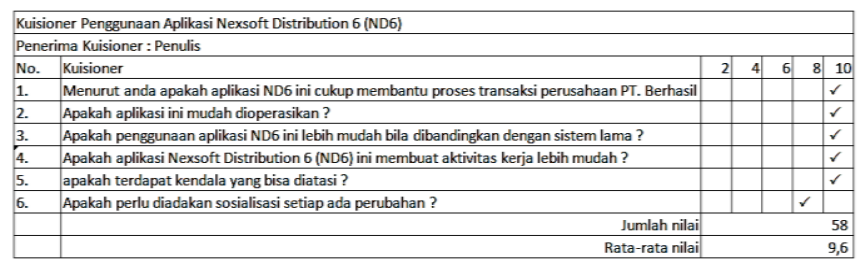


International Journal of Computer and Information System (IJCIS)

Peer Reviewed - International Journal

Vol : Vol. 01, Issue 02, August 2020

e-ISSN : 2745-9659

https://ijcis.net/index.php/ijcis/index

\subsection{Analysis SWOT}

In the SWOT analysis process that researchers have done, it produces the following data.

Table 4. SWOT Analysis Results

\begin{tabular}{|c|c|c|c|}
\hline STRENGHTS & WEAKNESSES & OPPORTUNITIES & THREATS \\
\hline $\begin{array}{lr}\text { Bosnet, } & \text { sistem } \\
\text { informasi } & \text { perangkat } \\
\text { lunak yang dirancang } \\
\text { khusus r untuk } \\
\text { membantu } & \text { aktivitas } \\
\text { distribusi r sehari- } & \text { harinya. Sehingga } \\
\text { keberadaannya } \\
\text { sangat membantu } \\
\text { karena sistem ini } \\
\text { dibuat/dirancang } \\
\text { sesuai dengan } \\
\text { kebutuhan } \\
\text { perusahaan. }\end{array}$ & \begin{tabular}{|lr} 
Bosnet, pada \\
perangkat lunak ini \\
mobile interface nya \\
belum dapat \\
digunakan.
\end{tabular} & \begin{tabular}{|lrr} 
Bosnet, & memiliki \\
daya & saing & yang \\
sangat & tinggi & dalam \\
dengan & Distribution \\
Management & System \\
yang & lain & karena \\
keunggulan- & \\
keunggulan & yang \\
dimiliki. & \\
\end{tabular} & $\begin{array}{l}\text { Seiring dengan } \\
\text { berkembangnya } \\
\text { zaman dan teknologi, } \\
\text { muncul banyak } \\
\text { Distribution } \\
\text { Management System } \\
\text { yang lain, yang } \\
\text { tentunya tidak kalah } \\
\text { unggul nya dengan } \\
\text { Bosnet, sehingga } \\
\text { Bosnet diharuskan } \\
\text { melakukan update } \\
\text { agar tidak tertinggal } \\
\text { dengan adanya } \\
\text { perkembangan } \\
\text { zaman dan teknologi } \\
\text { yang ada. }\end{array}$ \\
\hline
\end{tabular}

\section{CONCLUSION}

PT. Succeed Solo is a distribution company that distributes products from manufacturers to retailers or from producers to consumers. In the process of daily company activities, a system is needed to facilitate recording of basic activities of company transactions.

ND6 is the main operating system for every trading business in carrying out daily activities. With Bosnet distributors can manage stock (including damaged and returned goods), manage goods for canvass, take orders or sell goods canvass, manage accounts receivable, sales and accounts payable. Bosnet also helps distributors prepare monthly tax reports, manage discounts and promotions, system functionality or questionnaire tests. Shown the percentage of the system test value.

\section{REFERENCES}

[1] BradEnterprise, Jubilee. 2016. "Belajar Java, Database, dan NetBeans dari Nol”. Jakarta: PT Elex Media Komputindo.

[2] Nexsoft Jakarta. 2016. "Dengan Produk dan Layanan kami, bisnis anda akan makin sukses dan kompetitif" di http://www.nexsoft.co.id/index.html (diakses pada 25 Januari 2021).

[3] Purnama, Chamdan. 2016. Sistem Informasi Manajemen. Mojokerto: Insan Global.Winarto, 2012, Panduan Menguasai PHP \& MySQL Secara Otodidak, Mediakita.

[4] Rusdiana, H.A., dan Moch. Irfan. 2014. "Sistem Informasi Manajemen”. Bandung: CV Pustaka Setia.

[5] Utomo, I. C., Rokhmah, S., \& Muslihah, I. (2020). Web Based Distribution of Zakat, Infaq, and shodaqoh (Case Study Of Surakarta City Region). International Journal of Computer and Information System (IJCIS), 1(1).

[6] Muqorobin, Muqorobin, Siti Rokhmah, Isnawati Muslihah, and Nendy Akbar Rozaq Rais. "Classification of Community Complaints Against Public Services on Twitter." International
Journal of Computer and Information System (IJCIS) 1, no. 1 (2020).

[7] K. Kusrini, E. T. Luthfi, M. Muqorobin and R. W. Abdullah, "Comparison of Naive Bayes and K-NN Method on Tuition Fee Payment Overdue Prediction," 2019 4th International Conference on Information Technology, Information Systems and Electrical Engineering (ICITISEE), Yogyakarta, Indonesia, 2019, pp. 125-130, doi: 10.1109/ICITISEE48480.2019.9003782.

[8] Muqorobin, M., Apriliyani, A., \& Kusrini, K. (2019). Sistem Pendukung Keputusan Penerimaan Beasiswa dengan Metode SAW. Respati, 14(1).

[9] Abdullah, Robi W., et al. "Keamanan Basis Data pada Perancangan Sistem Kepakaran Prestasi Sman Dikota Surakarta." Creative Communication and Innovative Technology Journal, vol. 12, no. 1, 2019, pp. 13-21.

[10] Muqorobin, M., Hisyam, Z., Mashuri, M., Hanafi, H., \& Setiyantara, Y. (2019). Implementasi Network Intrusion Detection System (NIDS) Dalam Sistem Keamanan Open Cloud Computing. Majalah Ilmiah Bahari Jogja, 17(2), 1-9. 